\title{
KEJAWAAN DAN KEKRISTENAN: NEGOSIASI IDENTITAS ORANG KRISTEN JAWA DALAM PERSOALAN DI SEKITAR TRADISI ZIARAH KUBUR
}

\author{
Oleh: \\ Emmanuel Satyo Yuwono \\ Fakultas Psikologi Universitas Sanata Dharma Yogyakarta \\ Email: nuel_waterblue@yahoo.com
}

\begin{abstract}
Abstrak
Ziarah kubur merupakan tradisi yang melekat dalam tradisi masyarakat Jawa. Tradisi ini tidak hanya menjadi wujud hormat bagi leluhur mereka, namun memiliki pemaknaan akan peristiwa kematian. Bagi orang Jawa persitiwa kematian tidak berarti kepunahan melainkan kesuburan. Orang-orang melakukan ritual ziarah kubur untuk mendoakan dan menyelipkan harapan atau berkah pangestu melalui leluhur mereka. Permohonan ini dipanjatkan tidak hanya melalui leluhur mereka secara pribadi, namun juga leluhur mereka secara komunal yang sering disebut dengan pepunden. Sebagai wujud nyata penghormatan leluhur secara komunal, maka dikenal adanya tradisi slametan, merti desa, dan bahkan dihadirkan melalui pertunjukan wayang kulit. Semua tradisi ini menjadi ritual di sekitar ziarah kubur karena terdapat wujud hormat dan permohonan melalui leluhur mereka, yang semuanya mengarah pada penunjukan identitas manusia Jawa.

Tradisi di sekitar ziarah kubur ini tergambar di tengah masyarakat Desa Banyubiru. Sebuah desa yang terletak di lereng gunung Telomoyo dan di dekat Rawa Pening. Kondisi alam semacam ini menyebabkan konsepsi ritual penghormatan leluhur semakin kuat. Namun, di tengah masyarakat Banyubiru muncul usaha purifikasi agama yang hadir melalui ajaran Gereja Kristen Jawa. Ajaran Kristen memandang bahwa setelah kematian tidak ada keterhubungan antara yang masih hidup dengan roh orang meninggal. Orang yang meninggal sudah langsung berada di Surga. Pemahaman ini didasarkan atas teks Alkitab dan tafsiran dari para Pendeta.

Jemaat Gereja Kristen Jawa akhirnya harus menegosiasikan identitasnya antara kejawaan dan kekristenan. Untuk melihat mekanisme negosiasi identitas, kajian ini menggunakan pendekatan Foucault tentang panoptikon. Dari hasil kajian yang telah dilakukan ternyata teori panoptikon Foucault masih terbatas. Foucault melihat adanya pengawasan berasal dari satu titik saja atau bersifat tunggal. Dalam kajian ini ternyata ada dua pengawasan yang mempengaruhi negosiasi identitas. Tuhan yang dihadirkan melalui Alkitab sebagai usaha purifikasi dan aturan komunal dalam masyarakat. Akhirnya penelitian ini menunjukkan bahwa usaha purifikasi tidak berhasil secara total. Kegagalan purifikasi ini disebabkan karena pengetahuan jemaat GKJ yang dipengaruhi oleh kekuasaan di sekitarnya, dalam hal ini kekuatan tradisi lokal. Jemaat GKJ tetap melakukan ziarah kubur namun di sisi lain tidak melakukan ritual dan pemaknaan seperti dalam tradisi Jawa.
\end{abstract}

Kata Kunci : Negosiasi, identitas, Kejawaan, Kekristenan, ziarah kubur 


\section{Pendahuluan}

Peristiwa kematian dalam berbagai tradisi dan agama tentu memiliki praktek ritual masing-masing. Ritual tersebut memiliki makna-makna yang mendalam dan sulit untuk dilepaskan sebagai sebuah tradisi. Ritual tersebut tidak hanya ketika perawatan jenazah, tetapi juga kelanjutan setelah itu. Seperti apa yang dilakukan dalam tradisi Jawa.

Manakala kita membicarakan mengenai Jawa, kata Jawa cenderung diasosiasikan dengan gagasan terhadap usaha-usaha menjaga dan meneruskan tradisi leluhurnya. Di sini dapat dikatakan bahwa dalam masyarakat Jawa tradisi dipandang berasal dari naluri yang berada di luar pengalaman sehari-hari. Tradisi ini tidak muncul begitu saja, namun rupanya bersumber dari pengetahuan orang mengenai kebiasaan-kebiasaan yang telah berlangsung semenjak jaman kuno yang kini tidak secara tepat dipahami dan diurai kembali. Oleh karena itu dalam menjalankan tradisi, orang sering mendengarkan pertimbangan orang tua atau tetangga yang dianggap tahu (Subagyo, $2004: 63$ )

Salah satu tradisi Jawa yang berkaitan dengan peristiwa kematian dan usaha untuk menjaga tradisi leluhurnya adalah tradisi ziarah kubur. Peneliti tertarik untuk melihat tradisi ziarah kubur karena begitu melekat dalam kehidupan sosial kemasyarakatan. Bagi masyarakat Jawa, ziarah kubur menjadi tradisi yang dilakukan secara turun menurun sebagai wujud penghormatan terhadap leluhurnya. Masyarakat Jawa melakukan ziarah kubur yaitu dengan melakukan bersih-bersih makam dan juga mendoakan baik itu leluhur atau sanak saudaranya yang di makamkan di situ.

Orang Jawa menghormati roh leluhur dan berupaya manunggal dengan Tuhan, dilakukan secara mistik. Berbagai ritual mistik selalu dilakukan secara individu maupun kolektif. Namun, tingkatan masingmasing pada saat melakukan sangat berbeda antara yang satu dengan yang lainnya. Tolstoy (James, 2003:512) berpendapat bahwa mistik bersifat tak tertandingi, di dalamnya menancap iman. Keimanan menyebabkan seseorang hidup. Ritual mistik dalam menghormati roh leluhur tersebut nampak dalam tradisi ziarah kubur. Berbagai ritual dilakukan dengan penuh keyakinan akan memperoleh pengestu atau sebagai wujud hormat pada leluhur. Berbagai sesaji disiapkan sebagai sarana seperti bunga, kemenyan, air, dan lain-lain yang diyakini memiliki makna dan fungsi tertentu.

Saat ini muncul permasalahan bagi orang Jawa ketika berkembang atau 
bangkitnya agama-agama wahyu. Perkembangan agama menjadi polemik atau permasalahan di tengah kehidupan sosial masyarakat, karena tidak sejalan dengan tradisi-tradisi budaya Jawa. Cara beragama orang Jawa yang semula lentur menjadi sedikit kaku. Ini dipengaruhi oleh usaha purifikasi agama yang hadir melalui ajaranajaran agama, mereka ingin menjalankan agama secara utuh dan murni.

Salah satu usaha purifikasi sebagai wujud kebangkitan agama tersebut adalah ajaran agama Kristen yang melarang melakukan praktek ziarah kubur dengan berbagai ritualnya. Bagi pemeluk agama Kristen tidak perlu melakukan ziarah kubur karena memiliki keyakinan bahwa arwah orang meninggal tersebut telah masuk surga, sehingga tidak perlu berdoa di depan makam. Orang Kristen memiliki wacana tersebut di dapat dari apa yang diungkapkan oleh para pemuka agama mereka melalui dogma-dogma. Sering kali konsepsi ajaran sebagaimana yang dirumuskan itu dianggap sebagai kekuatan yang paling benar dan sempurna (Hardjana, 2005). Bagi mereka antara orang yang sudah meninggal dengan yang masih hidup sudah tidak memiliki hubungan apapun. Konsep yang berbeda dari tradisi Jawa. Orang jawa masih memiliki keyakinan adanya hubungan antara dunia roh leluhur dengan dunia mereka, baik dalam wujud pangestu atau wujud hormat pada leluhur.

Wacana dilihat sebagai produksi pengetahuan melalui bahasa, dan bahasa lebih dalam kaitannya dengan praksis sosial. Karena praksis sosial memerlukan makna dan makna mempertajam serta mempengaruhi apa yang kita lakukan, maka semua praktik sosial mengandung dimensi wacana (Haryatmoko, 2010:10). Maka, ajaran kristen yang menjadi praktik sosial merupakan sebuah wacana dalam menyikapi tradisi ziarah kubur. Dalam penelitian ini yang menjadi permasalahan adalah ketika adanya dua wacana yang bertabrakan. Wacana kebangkitan agama yang berupa larangan ziarah kubur oleh agama Kristen dengan tradisi Jawa yang meyakini dan menjadikan ziarah kubur sebagai bentuk bakti hormat kepada leluhur melalui gagasan yang terkonstruksikan secara sosial.

Fenomena tarik ulur akan identitas ini terjadi di lingkungan sosial masyarakat Desa Banyubiru. Sebuah desa yang terletak di Kabupaten Semarang Provinsi Jawa Tengah ini masih memegang teguh ajaran tradisi Jawa, salah satunya tradisi ziarah kubur.

Kajian ini ingin melihat bagaimana negosiasi identitas orang Jawa yang beragama Kristen Jawa dalam menyikapi 
tradisi ziarah kubur. Metode yang digunakan adalah Lived Experience, yaitu, pengalaman hidup secara langsung orang Jawa yang beragama Kristen dalam menyikapi wacana tentang ziarah kubur. Seperti yang disampaikan Paula Saukko, penelitian dalam kajian budaya meliputi pengalaman hidup, wacana, dan juga konteks sosial (Saukko, 2003:33). Lived Experience di sini bukanlah pengalaman langsung secara murni dalam masyarakat, namun sudut pandang peneliti dengan teori Foucault juga sangat berpengaruh.

\section{"Identitas Kejawaan" Masyarakat Desa Banyubiru}

Sosok manusia utama dalam konsep manusia Jawa berdimensi pada dua wilayah, kepada Tuhan (vertikal) dan kepada sesama manusia (horisontal) (Mulyana, 2006). Tuhan sebagai sandaran manusia yang dihadirkan melalui berbagai ritual dan sesaji ini menjadi dimensi vertikal manusia, sedangkan pada taraf horisontal tergambar dalam simbol bahasa bisa ajur ajer (mampu beradaptasi dan menyeleksi). Konsep ini menganjurkan kepada orang Jawa agar selalu dapat menempatkan dirinya secara adaptif di manapun berada. Dua dimensi ini membawa manusia Jawa untuk bisa menempatkan dirinya baik secara komunal maupun secara vertikal.

Pergumulan orang Jawa akan jati dirinya tergambar dalam berbagai permenungan yang cukup mendalam. Orang Jawa selalu mencari asal-usal hidupnya. Asal-usul keberadaan manusia yang sering dikenal dengan sangkan paraning dumadi, yaitu sebuah pemahaman masyarakat Jawa tentang asal muasal kejadian manusia.

Tentang asal-usuling dumadi ini merupakan sebuah pertanyaan yang sangat mendasar, karena setiap perilaku orang Jawa selalu ingin mengetahui bibit kawit (asal mula), atau wiji (biji). Pemahaman ini melahirkan lakon wayang yang cukup terkenal, yaitu Dewa Ruci. Sebuah lakon wayang yang menggambarkan tercapainya kebahagiaan sejati dengan cara menunggalnya kawula (Bima) dengan Gusti (Dewaruci). Lebih dalam lagi, Magnis (1988:116-117) memberi penafsiran, bahwa Dewaruci yang kerdil dan mirip dengan Bima tiada lain adalah "batin Bima sendiri". Oleh karena itu, sesudah memasuki batinnya sendiri, Bima teringat bahwa pada hakikatnya ia berasal dari unsur Illahi. Dalam hal itu, ia kembali menghayati kesatuan hakikinya dengan asal-usulnya itu, kesatuan hamba dan Tuhan (kawula Gusti). Melalui kesatuan itu manusia mencapai apa 
yang oleh orang Jawa disebut kawruh sangkan paraning dumadi: pengetahuan (kawruh) tentang asal (sangkan) dan tujuan (paran) segala apa yang diciptakan (dumadi). Oleh sebab itu, ritus kejadian desa yang sering dikaitkan dengan sejarah desa atau bersih desa merupakan tindakan introspeksi akan asal kehidupan manusia, yang didalamnya terkandung rasa syukur dan harapan bagi masa depan. Rasa syukur atas asal mula kehidupan melalui leluhur atau cikal bakal desa mereka. (Hidajat, 2006)

Manusia Jawa dalam perilakunya untuk mengetahui asal mula dan akhir kehidupannya selalu dilakukan dengan berbagai cara. Tidak hanya berhenti pada sebuah tradisi bersih desa saja, namun mencoba mencari lebih mendalam sejarah leluhur mereka

Berdasarkan cerita rakyat atau cerita babad, Banyubiru merupakan salah satu daerah yang memiliki sebutan daerah "Bumi Perdikan”. Meskipun saat ini sebenarnya sebutan tersebut secara resmi dalam pemerintahan sudah tidak dipakai, namun Banyubiru masih mempertahankan identitas tersebut, seperti yang tertulis di Gapura Desa Banyubiru dengan tulisan Bumi Perdikan Banyubiru. Usaha mempertahankan identitas tersebut sebagai wujud hormat bakti kepada leluhur di Banyubiru, masyarakat menyadari bahwa Bumi Perdikan, berdasarkan wawancara dengan Bapak Sri Anggoro (Kepala Desa Banyubiru) tanggal 2 Maret 2013 merupakan penghargaan atas jasa leluhur mereka. Bumi Perdikan sendiri pada waktu itu merupakan daerah yang dibebaskan atau tidak perlu membayar pajak atau asok gelondong pengareng-areng kepada kerajaan penguasa sebagai suatu kewajiban.

Wacana tentang kebenaran akan sejarah Bumi Perdikan Banyubiru mampu menjadi kekuatan dalam pembentukan identitas manusia Jawa, namun disisi lain juga bisa berakibat sebaliknya yaitu menghancurkan. Ini sesuai dengan ungkapan Foucault "Wacana menghasilkan kekuatan yang memperkuat, tetapi juga bisa menghancurkan, membuat rapuh dan memungkinkan untuk menggagalkan" (Foucault, 1978: 101).

Wacana sejarah Bumi Perdikan ini semakin diperkuat dengan keberadaan para tokoh yang menjadi pepunden seperti Sora Dipoyono, Kyai Joyoproyo, dan juga Kebo Kenanga. Para tokoh ini semakin memperkuat identitas Kejawaan masyarakat Banyubiru karena semasa hidupnya menjadi pahlawan bagi kerajaan-kerajaan di Jawa, bahkan sampai saat ini diyakini oleh 
masyarakat Banyubiru masih memiliki kekuatan untuk membantu atau menjaga keadaan Desa Banyubiru seperti semasa hidupnya. Keyakinan ini mengantar pada ritual slametan dan ziarah kubur yang senantiasa hadir sebagai wujud penghormatan baik dilakukan secara individu maupun komunal.

Ziarah kubur, berdasarkan hasil wawancara dengan Bapak Martoyo (Juru Kunci Makam Kyai Joyoproyo) tanggal 15 Februari 2014, merupakan cara pandang beberapa masyarakat di Desa Banyubiru sebagai wujud bakti dan hormat pada leluhur mereka, seperti yang diungkapkan oleh Bapak Martoyo berikut:

"Nyekar (ziarah kubur) itu
menandakan kalau yang
dimakamkan ada yang ngopeni
(merawat), karena orang tua saya
sudah meninggal saya mendoakan
didepan makam tersebut, njaloke
ngapuro tinebihno seko siksa neraka
dicaketke karo Gusti Allah
(memintakan maaf atas dosa dan
dijauhkan dari neraka, didekatkan
pada Gusti Allah). Dan pasti nanti
leluhur kita akan juga mendoakan
dan melindungi kita yang masih
hidup."

Ziarah kubur menjadi cara pandang yang kuat bagi masyarakat Jawa seperti di Desa Banyubiru. Dengan ziarah kubur ini masyarakat memiliki keyakinan, arwah tersebut memang pantas dimintai berkah agar membantu anak cucu. Roh leluhur dianggap yang menjadi penjaga bagi kehidupannya.

Penghayatan masyarakat Desa Banyubiru berkaitan dengan kejawaan juga dipengaruhi oleh kondisi geografis. Desa Banyubiru sendiri merupakan daerah pedesaan yang terdiri dari daerah persawahan, pegunungan, rawa, dan juga dataran biasa. Kondisi alam ini membuat sebagian besar masyarakat Banyubiru menggantungkan hidupnya pada alam. Kesinambungan hidup yang bergantung dari alam menuntut masyarakat untuk selalu mensyukuri dan memohon kesuburan akan hasil bumi. Penyatuan diri dengan alam ini dibarengi dengan sikap menghormati dan memohon pada leluhur, agar ditolong dalam berbagai kesulitan hidup.

\section{Sejarah Kristenisasi di Jawa : Berawal dari Kolonialisme}

Awal munculnya ajaran Kristen di Nusantara tidak bisa dilepaskan dari kolonialisme. Usaha Kristenisasi dilakukan oleh orang Portugis, terutama di daerah Maluku pada abad XVI. Pada abad XVII, saat Belanda berhasil menghalau Portugis dari wilayah tersebut, maka 
mengembangkan Calvinisme di antara orang-orang Maluku yang ketika itu sudah beragama Katolik. Banyak orang Maluku yang bergama Kristen supaya tercatat, mereka menjadi serdadu yang diperbantukan pada pasukan Belanda. Mereka dikirim ke kawasan militer Belanda yang utama, seperti Batavia, Semarang, dan Surabaya. Berarti merekalah yang pertama-tama membentuk jemaah Kristen pribumi di Pulau Jawa. Akhir abad XVIII, jumlah mereka mencapai 5000 jiwa, walaupun menurut laporan para misionaris hanya $8 \%$ yang mengikuti kebaktian di Gereja-gereja (Müller-Krüger, 1959; Guillot, 1985: 4)

Gereja Kristen Jawa berkembang pertama kali di Jawa Timur. Para penginjil awam seperti Coenard Laurens Coolen (lahir tahun 1773), Yohanes Emde (lahir tahun 1774), dan Kyai Ibrahim Tunggul Wulung (1885) melakukan pekabaran Injil di Jawa Timur. Pada awal mulanya terjadi ketegangan antara Kristen "Jawa" dan juga Kristen "Landa" (Soekotjo, 2009: 100).

C. L. Coolen, yang lahir di ungaran pada tahun 1773 dari ayah seorang Rusia dengan ibu putri keturunan Pangeran Kajoran menyebut ajarannya sebagai Kristen "Jawa" bukan Kristen "Landa". Dalam ajaran ini Kekristenannya sangat kental dengan kejawaan, tembang, wayang, dan rapal, bahkan dengan yang berbau Islam seperti dzikir. Kekristenan tidak membuang unsur-unsur Jawa dari para pengikutnya, oleh sebab itu sakramen yang dianggap menjadi unsur Kristen Landa tidak diberikan kepada pengikutnya supaya jemaatnya tidak terhanyut menyamakan diri dengan orang Belanda dan meninggalkan cara hidup kejawaannya sendiri. Prinsipnya, sebagai orang Kristen, orang Jawa itu harus tetap Jawa.

Jemaat tanpa sakramen ini akhirnya harus menghadapi kenyataan yang lain ketika bertemu dengan kelompok jemaat Johannes Emde mereka harus mau menerima baptisan. Johanes Emde lahir tahun 1774 di Jerman dari keluarga petani. Pada saat pemerintahan Daendels dia masuk tentara, ketika Raffles memerintah dia mengundurkan diri dari dinas militer. Sejak saat itu dia tinggal di Surabaya dan menikah dengan gadis Jawa dari kalangan ningrat, yang berasal dari kraton Solo. Mulai saat itu, bersama keluarganya Emde menyebarkan ajaran Kristen dengan menyebarkan brosur. Dalam kalimat awal bertuliskan "wiwitaning Injile Yesus Kristus Putrane Allah..." (permulaan Injil Yesus Kristus, Putra Allah..). Beberapa orang menerima brosur bertanya-tanya bagaimana Tuhan bisa punya anak. Salah satunya seorang Modin yang 
bernama Pak Dasimah. Pada tahun 1838 Pak Dasimah berdasarkan informasi yang dia peroleh bersama dengan sembilan orang lainnya justru menemui Coolen. Dari Coolen dia mendapatkan dasar-dasar agama Kristen seperti Syahadat, Bapa Kami, dan Sepuluh Firman Tuhan (Guillot, 1985: 23).

Akibatnya, beberapa orang pengikut Coolen seperti Singotaruno, Tosari, Kunto, dan Anip mencari dan mendapatkan sakramen baptis. Kejadian ini memicu kemarahan Coolen, yang berhujung pengusiran terhadap para pengikutnya. Pengusiran ini justru membuat ajaran Kristen berkembang ke beberapa daerah, seperti Kyai Jakobus Singotaruna dan Paulus Tosari tinggal di Sidokare dekat Sidoarjo. Abisai Ditotaruna membuka pemukiman di Mojowarno dan menjadi lurahnya.

Tanpa disadari identitas Kristen terbentuk karena wacana yang saat itu berkembang. Ajaran Coolen dianggap tradisional dan perlu ditinggalkan. Justru sebaliknya identitas asing dianggap lebih kuat,ini karena tidak terlepas dari kedudukan Belanda yang lebih tinggi dibanding penduduk pribumi.

\section{Pengaruh dan Proses Pembentukan Identitas Kristen Jawa di Banyubiru}

Perkembangan Gereja Kristen Banyubiru dipengaruhi oleh berbagai macam faktor. Tidak hanya letaknya yang berdekatan dengan Salatiga sebagai basis perkembangan ajaran Kristen, namun juga karena faktor-faktor lain. Berbagai faktor tersebut mencakup Misonaris dan cara penyebaran. Kedua faktor ini menjadi kekuasaan yang tidak mendominasi, namun lebih menjadi kekuasaan yang produktif dalam menciptakan pengetahuan.

Foucault memandang bahwa "Dalam kekuasaan tidak ada unsur penaklukan dalam bentuk kekerasan atau aturan" (Foucault, 1978: 92). Pengaruh dan proses pembentukan identitas Kristen Jawa hadir tanpa adanya proses pemaksaan maupun kekerasan. Namun, penaklukan kekuasaan ini hadir melalui dogma yang dibawa oleh para penyebar ajaran Kristen.

Para penyebar ajaran Kristen yang hadir di Banyubiru antara lain Bapak Witono, Bapak Pdt Pinoejadi, dan juga Bapak Pdt Setyo Utomo. Setiap pemimpin memiliki pandangan yang berbeda-beda berkaitan dengan tradisi lokal. Bapak Witono memiliki cara pandang yang sama dengan Bapak Pendeta Pinoejadi, memiliki iman Kristen yang teguh, dalam artian tidak memberi ruang bagi tradisi Jawa yang bertentangan dengan ajaran Kristen. 
Berdasarkan wawancara dengan Bapak Sisiwantoro (Jemaat GKJ Banyubiru) tanggal 18 Oktober 2013 salah satu contoh yang diungkapkan jemaat GKJ bahwa "Pak Witono tidak pernah mengadakan genduren, baik pada waktu nyunatke atau peringatan kematian saudaranya.

Saat ini GKJ Banyubiru dibawah GKJ Ambarawa dipimpin oleh Bapak Pdt Setyo Utomo. Bapak Setyo Utomo lahir di Tuban, Jawa Timur tahun 1968. Ketertarikannya pada bidang Teologi membuat Pak Setyo memutuskan untuk belajar di Universitas Kristen Duta Wacana, menyelesaikan pendidikan Teologinya pada tahun 1994. Berkarya di GKJ Ambarawa sejak tahun 1996, sedangkan menjadi pendeta tahun 1997 sampai sekarang. Usianya yang muda, lebih bisa menerima tradisi-tradisi lokal. Ini karena secara teologis sudah memiliki cara pandang yang berbeda. Inilah alasan mengapa ajaran yang dibawanya berbeda dibanding pendeta angkatan sebelumnya, inilah ungkapan Bapak Pdt Setyo (pdt GKJ Ambarawa) tanggal 6 Juni 2013:

"Dahulu para pendeta menjaga pemurnian, itu karena masih pertumbuhan atau rintisan jadi harus dijaga dan didoktrinasi dengan kuat. Dalam konteks sekarang tidak bisa harus dianggap dewasa jadi sudah bisa mengambil keputusan etis sendiri."

Berangkat dari situ, maka corak Gereja dahulu dengan sekarang berbeda. Gereja yang dewasa di era saat ini seharusnya bisa menerima tradisi lokal yang ada. Maka, peran pemuka agama menjadi sangat penting dalam membentuk sebuah tradisi baik sebagai suatu cara pandang pribadi maupun secara hidup bermasyarakat. Gereja yang dewasa menurut Bapak Pdt Setyo Utomo ini tidaklah mudah, kenyataannya dalam diri jemaat tetap muncul sebuah tarik ulur akan identitas.

Pembentukan identitas Kristenan Jawa di Banyubiru selain dipengaruhi oleh peran para penyebar ajaran juga cara penyebaran. Cara penyebaran di sini berkaitan dengan bagaimana caranya ajaran Kristen bisa hadir dan berkembang di tengah Desa Banyubiru. Secara garis besar ada dua cara yaitu berdasarkan dogma melalui Alkitab yang ditafsirkan Pendeta dan juga berbagai kegiatan dari daerah sekitar Banyubiru. Inilah salah satu ungkapan jemaat GKJ Bapak Suratno tanggal 20 Mei 2013 yang rutin mengikuti pendalaman Alkitab:

"Pendalaman Alkitab semakin bisa menunjukan bagaimana orang Kristen yang benar berdasarkan ajaran Alkitab, dengan cara bertukar pengalaman berdasar atas 
firman Tuhan, kalau ada kesulitan baru tanya Bapak Pendeta.”

Penunjukan kebenaran akan identitas Kekristenannya selain di hadirkan melalui peran Pendeta ataupun misionaris, ternyata juga atas tafsiran Alkitab yang dilakukan oleh jemaat sendiri. Tafsiran teks Alkitab menjadi kekuatan cara pandang mereka dalam hidup di tengah msayarakat. Tafsiran teks Alkitab menjadi pembenaran yang berfungsi tidak hanya sekedar berfungsi sebagai aturan hidup, namun menjadi cara hidup dan perjuangan hidup, singkat kata hidup demi Tuhan. Permasalahan dalam kehidupan masyarakat sering dibicarakan dalam Pendalaman Alkitab dengan dicari kebenarannya berdasar atas Alkitab. Mereka menjadikan Alkitab sebagai panutan atau kebenaran dalam kehidupan sehari-hari.

Keyakinan dan ajaran yang telah diterima melalui ajaran seorang misionaris ataupun penafsiran Alkitab merupakan sebuah wacana yang tentu mempunyai klaim kebenaran. Keyakinan dan ajaran ini menjadi kekuasaan yang selalu berimplikasi pada pengetahuan. Begitupun sebaliknya, tidak ada pengetahuan yang tidak berkorelasi dengan kekuasaan (Foucault, 1995: 27). Foucault ingin menegaskan bahwa penguasaan kekuasaan menciptakan objek-objek baru pengetahuan dan sistem informasi. Pengetahuan ketika digunakan sebagai suatu kebenaran yang akhirnya membatasi, mengatur, dan bahkan mendisiplinkan, maka secara tidak langsung akan menjadi cara pandang seseorang. Seperti cara pandang Bapak Suratno sebagai jemaat GKJ demikian:

"Nek wis yakin ki yo kudu diugemi (kalau sudah yakin ya dipercaya). Saya yakin kalau ajaran Alkitab menjadi kebenaran bagi jalan hidup saya, karena bagi saya Alkitab tidak hanya sekedar tulisan, melainkan lebih menjadi sabda yang hidup. Makanya ya menjadi panutan dalam hidup saya atau boleh dikata dadi sarana uripku (menjadi sarana hidup)."

Di sini terlihat bagaimana fungsi ideologis agama berperan sebagai pembenaran hidupnya, baik hidup dalam keluarga maupun bermasyarakat. Mayarakat yang terdiri dari berbagai keyakinan dan pandangan yang berbeda menjadikan jemaat GKJ memiliki cara pandang hidup yang berbeda, dalam meyakini peristiwa kematian dalam tradisi Jawa.

\section{Konsepsi ajaran Kristen yang hadir dalam usaha purifikasi}

Konsepsi ajaran Kristen mengantar pada perubahan hidup. Muncul kesadaran yang mendorong untuk merubah hidupnya. Perubahan ini mengarah pada usaha 
purifikasi atau pemurnian. Menurut Bruno Latour purifikasi adalah sebuah usaha yang total untuk membuat pemisahan manusia dari nonhumans seperti alam dan juga benda-benda yang memiliki kaitan dengan subjek transenden (Keane, 2007: 23). Purifikasi ini merupakan usaha untuk menjadi manusia yang lebih baik di hadapan Tuhan sesuai dengan ajaran-ajaran yang diterimanya. Lonergan (Prasetya (1993: 76) menjelaskan Agama adalah salah satu bentuk cinta yang radikal dan total kepada Tuhan. Kemampuan untuk memilih Tuhan secara radikal, entah dalam taraf akal budi, moral dan cinta ini digerakkan oleh kebebasannya untuk memilih apa yang paling bernilai, dan oleh kehendak untuk mewujudkan nilai tertinggi tersebut dalam hidupnya.

Usaha purifikasi hadir dalam Kristen Calvinis yang datang bersama dengan para penjajah Belanda. Bagi Calvinisime, praktek purifikasi agama berjalan seiring dengan rasionalisme. Beragama yang baik berarti perlu rasional. Dia perlu menjauhkan diri dari tahayul dan juga pemberhalaan atas benda. Sejauh ini, Kekristenan menjadi panduan dan juga ekspresi purifikasi atau pemurnian (Keane, 2007: 77).

Usaha pemurnian nampak dalam jemaat GKJ Banyubiru baik secara radikal, entah dalam taraf akal budi, moral dan cinta yang berkaitan dengan tradisi-tradisi Jawa, mulai dari slametan, penghormatan pada leluhur (ziarah kubur), dan juga tradisitradisi lainnya. Selain itu juga pemaknaan akan kematian. Kesemuanya mengarah pada tarik ulur sikap penentuan identitas Jemaat GKJ, antara Kejawaan dan Kekristenan.

Tradisi ziarah kubur tidak bisa dilepaskan dari peristiwa kematian. Ziarah kubur dilakukan untuk menghormati orang yang telah meninggal. Bagi orang Jawa peristiwa kematian dan juga peristiwaperistiwa yang menyertai kematian dari waktu ke waktu selama tiga tahun atau seribu hari selalu dikaitkan dengan slametan. Slametan dalam tradisi Jawa tidak bisa begitu saja dilepaskan dari ajaran Islam. Slametan merupakan sebuah contoh yang oleh Beatty merupakan "ambiguitas yang teratur" unsur-unsur multivokalnya tidak hanya tindakan atau simbol-simbol material, tetapi kata-kata yang hanya akan bermakna apabila diucapkan selama upacara berlangsung. Orang-orang dengan orientasi yang berbeda secara bersama-sama mendatangi suatu ritual dan merajut kesepahaman. Signifikansi ritual ini bergantung pada apa dan bagaimana peserta slametan menggunakan konsep-konsep kunci yang sebagian berasal dari Islam 
(seperti pembacaan ayat al-Qur'an dan pemujaan atau Shalawat pada Nabi Saw) (Beatty, 2001: 38). Pemikiran masyarakat Jawa tersebut turut mendasari perilaku masyarakat sehari-hari, sehingga masyarakat Jawa senantiasa berusaha agar roh-roh leluhur selalu berkenan dengan manusia. Oleh karena itu, slametan menjadi ritual menjaga keselarasan dan keharmonisan hubungan dengan roh gaib (leluhur) (Wisnumurti, 2012: 150).

Pemaknaan akan tradisi lokal bagi Jemaat GKJ di Banyubiru memiliki perbedaan ketika dipimpin oleh Bapak Pdt Pinoejadi dengan Bpk Pdt Utomo. Pebedaan ini tampak dari kelunakan dan juga pemahaman terhadap berbagai tradisi lokal yang berkaitan dengan slametan, seperti hajatan nyunatke, nyadaran, genduren, dan juga slametan memperingati meninggalnya saudara.

Pada saat GKJ dipimpin oleh Bapak pdt Pinoejadi kekakuan sangat dirasakan, tidak ada kelenturan untuk menjalankan tradisi lokal. Berdasarkan wawancara dengan Bu Giyati (Jemaat GKJ Banyubiru) tanggal 10 Juni 2013 dalam peringatan peringatan leluhur mereka, baik 3 hari, 7 hari, 40 hari, dan seterusnya tidak diperkenankan. Hanya dilakukan doa penghiburan, karena semua telah diselamatkan Tuhan bagi yang percaya.

Perbedaan dirasakan oleh Jemaat GKJ Banyubiru di bawah Pdt Setyo Utomo. Ada kelenturan akan tradisi lokal, yaitu dengan meletakan tradisi lokal sebagai sebuah kehidupan sosial masyarakat. Seperti yang diungkapkan oleh Bapak Ratno berikut:

"Pak Setyo Utomo lebih modern, lebih lunak dibanding dengan pak Pinoejadi yang ditaktor meskipun sama-sama sarjana teologi. Kalau Pak Setyo Utomo memperbolehkan dan bahkan mau dipanggil untuk berdoa ketika ada hajatan 40 hari, 100 hari atau hajatan-hajatan lainnya."

Meskipun dalam tingkat pemaknaan tidak sama dengan penganut tradisi Jawa. Perbedaan ini tampak dari penghayatan slametan dalam ritual Jawa. Ini sesuai dengan pandangan Beatty, setiap orang akan memaknai slametan secara berbeda. Slametan mencerminkan suatu fungsi kritis dari simbolisme dalam tatanan yang secara ideologis beranekaragam, dan mendorong kesadaran kolektif menuju satu kesatu an, sehingga symbol multivokal dengan sendirinya menjadi sarana bagi sinkretisme (Beatty, 2001: 38). 
Strategi menempatkan identitas antara Jawa dan Kristen tampak dalam perilaku peringatan kematian ini. Tetap menjalankan ritual slametan sesuai dengan ritual Jawa, namun dimaknai secara berbeda. Bagi jemaat GKJ tidak ada unsur arwah leluhur, yang didoakan justru yang masih hidup atau yang ditinggalkan. Seperti apa yang diungkapan Bapak Sisiwantoro tanggal 22 Maret 2013, jemaat GKJ Banyubiru berikut:

"Ada kegiatan mengenang dan mengucap syukur, yang juga diikutkan dalam tradisi Jawa, misal 40 hari, 100 hari, dan bahkan 1000 hari. Intinya di sana hanya ngumpul dari jemaat, diungkapkan ucapan syukur karena masih diperbolehkan untuk mengenang segala kebaikannya. Kita tidak mendoakan arwah yang meninggal tapi berdoa untuk yang ditinggalkan supaya diberi kekuatan dan penghiburan."

Inilah bentuk negosiasi identitasnya, jemaat GKJ masih menyadari bahwa mereka adalah orang Jawa namun disisi lain dia juga orang Kristen. Sehingga dalam tradisi slametan, mereka tetap melakukan namun merubah maknanya. Orang dari luar akan tetap melihat bahwa mereka menjalankan ritual dalam tradisi Jawa seperti kelompok masyarakat Jawa yang lain.

\section{Penghormatan Leluhur dalam Tradisi Ziarah Kubur}

Masyarakat Jawa mencoba menghormati dan mendoakan leluhur mereka dengan berbagai cara, salah satunya melalui tradisi ziarah kubur. Berbagai sesaji dihadirkan saat ziarah kubur, mulai dari bunga, air, dan juga kemenyan. Tradisi semacam ini boleh dikatakan sebagai wujud pengorbanan anak-cucu kepada para leluhur yang telah sumare (meninggal) (Endraswara, 2006). Bahkan lebih dari sekedar sebuah penghormatan dan pengorbanan bagi leluhur mereka, masyarakat Jawa meyakini bahwa para leluhur yang telah meninggal pantas dimintai berkah agar membantu anak cucu yang masih hidup di dunia (Darusuprapta 1998:48).

Konsep ini berbeda dari pemahaman Krsiten tentang penghormatan pada leluhur. Meskipun pada dasarnya Jemaat GKJ juga melakukan penghormatan kepada leluhur mereka namun hanya sebatas mengenang segala kebaikan mereka, tanpa ada unsur mendoakan leluhur mereka. Seperti apa yang diungkapkan oleh Bapak Sisiwantoro, salah satu jemaat GKJ berikut:

"Ke kuburan bagi orang Kristen, khususnya Kristen Jawa itu tidak tabu. Bukan juga karena rikuh (sungkan) dengan tetangga, tetapi biasanya memiliki motivasi tersendiri, yaitu ingin mengenang kebaikan orang yang dimakamkan, 
tetapi tidak mendoakan yang dimakamkan disitu. Kita hanya nguri-nguri (melestarikan) budaya saja, tetapi kita mendoakan hanya keluarga yang ditinggalkan, karena kalau arwah sudah di tangan Tuhan.”

Jemaat GKJ nguri-nguri (melestarikan) budaya Jawa, ini memperlihatkan adanya usaha untuk menunjukkan diri mereka sebagai manusia Jawa. Negosiasi identitas Jawa dan Krsiten terlihat dari ritual ziarah kubur. Meskipun mereka memakanai kegiatan ini secara berbeda dari tradisi Jawa, namun tetap melakukan ziarah kubur. Bapak Suratno mengungkapkan bahwa inilah makna ritual ziarah kubur bagi jemaat GKJ di Banyubiru:

"Dilaksanakan tidak apa-apa tapi hanya untuk mengingat saja, mengingat kembali peristiwa dalam keluarga itu, doanya ya tetap kepada yang di atas. yang terpenting tertuju pada Tuhan, jangan sampai terpusat justru pada upacara adatnya."

Penghormatan ini memperlihatkan konsep yang berbeda dengan pemaknaan masyarakat Jawa. Bagi orang Jawa mendoakan leluhur memiliki esensi yang penting, bahkan memohonkan ampun atas kesalahan orang yang telah meninggal tersebut dan juga memohon pangestu untuk anak-cucu yang masih hidup.
Sikap ini dilakukan tidak bisa dilepaskan dari pengetahuan yang mereka dapatkan. Pengetahuan yang diperoleh dari berbagai kekuasaan di sekeliling mereka. Kekuasaan di sini tidak datang dari perorangan atau kelompok pemimpin. Menurut Foucault "Kekuasaan bukan sesuatu dominasi baik perorangan atau kelompok, seperti penguasa ataupun raja. Kekuasaan ada di mana-mana dan juga datang dari manapun" (Foucault, 1995: 63). Kekuasaan lebih bersifat produktif, baik berupa pengetahuan atau praktik-praktik yang mereka yakini sebagai kebenaran. Jemaat GKJ Banyubiru sebagai orang Kristen dan juga orang Jawa, dalam menyikapi soal ziarah kubur dan juga tradisi Jawa lainnya memunculkan berbagai macam strategi. Pengetahuan yang mereka peroleh mengantar pada pilihan identitas antara Jawa dan Kristen.

Pada dasarnya ajaran Kristen hanya menggunakan wadahnya untuk melakukan ziarah kubur namun memiliki tujuan dan pemaknaan yang berbeda. Dari sini terlihat sebagai sebuah tradisi yang berbeda dari tradisi Jawa. Tarik ulur akan idetitas tidak bisa dilepaskan dari segala ajaran yang selalu menjadi pengontrol. Jemaat GKJ meletakkan ajara Kristen sebagai cara pandang dalam hidup ditengah masyarakat. 
Namun, disisi lain secara komunal dalam masyarakat Jawa sudah memiliki tradisi secara turun menurun. Maka, pada bagian selanjutnya akan menjelaskan, bagaimana mekanisme tarik ulur identitas. Kekristenan dengan Alkitab yang menghadirkan "Tuhan" sebagai panotiknya, di satu sisi jemaat GKJ juga hidup ditengah masyarakat Jawa yang lekat dengan kosmologi Jawa. Kekuatan panotik ini memberikan kepatuhan yang akan membawa Jemaat GKJ pada dua kebenaran yang berbeda

\section{Kekristenan dan Kejawaan: Usaha} Memberikan Kepatuhan

Salah satu usaha memberikan kepatuhan adalah dengan menggunakan mekanisme Panopticon. Panopticon adalah sistem penjara yang dikembangkan oleh Bentham, berbentuk lingkaran, dimana ditengah berdiri menara pengawas. Dari menara tersebut di desain supaya pengawas dapat melihat tahanan dengan jelas, namun tahanan tidak bisa melihat pengawas. Sehingga sistem panoptik ini menstimulasi tahanan secara sadar dan permanen untuk selalu terawasi (Foucault, 1995 :200-201). Mekanisme panoptik menjadi pengawasan yang sangat efektif karena secara otomatis ada kekuatan untuk mengontrol tubuh, perilaku, dan berbagai kegiatan. Setiap orang dapat menggunakan mekanisme ini dalam kehidupan seperti dalam perusahaan, keluarga, masyarakat, dan juga sekolah. Pada dasarnya panoptikon memiliki kekuatan dalam usaha memberikan kepatuhan dan penyeragaman (Faucault, 1995: 202).

Jemaat GKJ dalam melakukan negosiasi identitas Kejawaan dan Kekristenan yang telah terlihat pada bagian sebelumnya sangat dipengaruhi oleh berbagai usaha penyeragaman atau kepatuhan, dan juga pendisiplinan seperti dalam mekanisme panoptik. Ajaran Alkitab yang menghadirkan "Tuhan" dan berbagai ajaran dogmatis menjadi pengawasan mereka dalam hidup sehari-hari. Dalam hal ini keterkaitannya memandang kematian dan berbagai ritual kematian dalam tradisi di sekitar ziarah kubur. Hal ini sesuai dengan pandangan Foucault bahwa "Panopticon adalah sebuah mekanisme luar biasa yang digunakan untuk meletakkan atau menghasilkan kekuasaan yang homogen" (Foucalut, 1995:202).

Jemaat GKJ dalam menegosiasikan identitasnya, tidak hanya Alkitab sebagai ajaran Kristen yang menjadi panoptik dalam dirinya, namun juga aturan komunal dalam masyarakat juga menjadi panoptik bagi dirinya. Ada usaha untuk memberi 
kepatuhan secara komunal. Ada berbagai pemahaman kosmologi Jawa dan juga aturan dengan berbagai hukuman yang tidak tertulis di tengah masyarakat Banyubiru.

Dalam hal ini analisis Foucault tentang panopticon bersifat terbatas ketika diterapkan dalam kasus Banyubiru, karena ada dua panoptik yang muncul untuk di negosiasikan. Namun analisa Panoptik Foucault tetap digunakan untuk membidik mekanisme negosiasi yang khas dari jemaat GKJ Banyubiru.

\section{“Alkitab" sebagai Panoptik}

Dalam ajaran Kristen, jemaat didorong untuk bersikap baik dan mengikuti ajaran Alkitab supaya terhindar dari "hukuman" Tuhan. Mereka juga menjamin perdamaian atau kehidupan abadi di surga setelah kematian. Gagasan ini sesuai dengan mekanisme panoptikon yang dibahas oleh Foucault. Orang-orang dalam penjara dengan sistem panopticon takut akan hukuman yang setiap saat diberikan karena para tahanan tidak bisa melihat ketika penjaga sedang mengawasi. Hal ini karena, menara tersebut di desain supaya pengawas dapat melihat tahanan dengan jelas, namun tahanan tidak bisa melihat pengawas (Foucault, 1995: 201). Sistem panoptik ini menstimulasi tahanan secara sadar dan permanen untuk selalu merasa terawasi. Tuhan yang dihadirkan melalui Alkitab sama dengan penjaga, memiliki kekuatan yang selalu mengawasi para tahanan. Para tahanan dengan demikian akan menjadi pengikut agama yang selalu merasa terawasi.

Ajaran Kristen meletakkan Alkitab dengan menghadirkan "Tuhan" sebagai usaha atau teknik mengatur individu. Ajaran Alkitab memberikan aturan-aturan yang melekat pada individu atau terinternalisasi oleh individu. Teks Alkitab bahkan semakin memiliki kekuatan ketika ditafsirkan oleh pendeta. Ajaran yang didapat oleh Jemaat GKJ melalui Alkitab ataupun tafsiran pendeta melekat dalam kehidupan seharihari, salah satunya dalam menyikapi dimensi kematian, dalam hal ini soal tradisi ziarah kubur.

Menurut Foucault "Panoptikon berfungsi sebagai semacam laboratorium kekuasaan. Berkat mekanisme pengamatannya, panoptikon memiliki efisiensi dan kemampuan untuk masuk ke dalam perilaku manusia; ilmu pengetahuan bergerak sejalan dengan kekuasaan, menemukan objek-objek pengetahuan baru di permukaan tempat kekuasaan dipergunakan" (Foucault, 1995: 204). Tuhan dihadirkan sebagai panoptik dalam 
menciptakan penyeragaman baik perilaku, ritus, dan juga keyakinan. Jemaat Kristen menyadari bahwa Tuhan selalu hadir di tengah kehidupan mereka, karena kuasa Tuhan yang maha kuasa. Ajaran bahwa Tuhan adalah satu-satunya tujuan hidup baik dunia maupun setelah kematian, memunculkan pengetahuan dan keyakinan bahwa setelah kematian seseorang sudah ada bersama Tuhan.

Agama dalam perannya membentuk dan mempertahankan identitas menghadirkan Tuhan. Hadirnya Tuhan yang memiliki segala "kuasa" menjadikan Jemaat merasa didampingi dalam hidupnya. Dalam diri manusia muncul kegembiraan ketika menjalankan ajaran dalam hal ini "surga".

Inilah yang menjadikan agama sebagai sebuah identitas memiliki praktik dan juga keyakinan. Agama sendiri tidak bisa dilepaskan dari mekanisme dan teknik kekuasaan normatif dan disipliner. Agama mengatur individu dan masyarakat melalui berbagai teknik, salah satunya dengan penyeragaman baik perilaku, bahasa, pakaian, maupun ritus (Haryatmoko, 2010: 101). Sehingga kehidupan komunal disini memiliki karakteristiknya tersendiri. Fungsi agama sebagai pengatur hidup manusia dengan menghadirkan Tuhan sebagai panoptik bagi penganutnya mempunyai tingkat efektifitas yang tinggi. Ini semakin memperlihatkan bagaimana agama memiliki peran dalam membentuk identitas seseorang.

\section{Aturan Komunal Masyarakat Jawa}

Kalau agama Kristen meletakan Alkitab sebagai teks sucinya dalam aturan hidup sehari-hari, orang Jawa mengambil dunia sehari-hari sebagai teks kunci dan tubuh manusia sebagai kitab sucinya (Beatty, 2001: 219). Ini memberikan gambaran bahwa aturan hidup manusia Jawa lebih didasarkan atas kehidupan sehari-hari (ajaran dari para leluhur) dibanding dengan teks tertulis.

Di Desa Banyubiru, mayoritas penduduknya beragama Islam namun masih meyakini tradisi Jawa. Di antara penduduk Muslim ini hanya sedikit orang yang pandai melafalkan Al-Quran ataupun ajaran-ajaran Islam. Dengan demikian boleh dikatakan Islam di Banyubiru adalah Islam Jawa. Menurut Woodward keunikan Islam Jawa bukan karena ia mempertahankan aspekaspek kebudayaan agama pra-Islam, tetapi karena konsep-konsep sufi menganai kewalian, jalan mistik, dan kesempurnaan manusia diterapkan dalam suatu formasi kultus kraton (imperial cult). Islam Jawa itu merupakan suatu model konsepsi Jawa tradisional mengenai aturan sosial, ritual, 
dan bahkan aspek-aspek kehidupan sosial seperti bentuk-bentuk kepribadian, hati dan penyakit (Woodward, 2006: 364).

Pemaknaan masyarakat Banyubiru terhadap tradisi ziarah kubur, sedekah bumi, dan juga penghormatan pepunden seperti pada penjelasan bab sebelumnya, memperlihatkan bahwa Banyubiru masih menjadikan ritual dan tradisi Jawa sebagai hal yang penting. Seperti misalnya dalam tradisi ziarah kubur, masyarakat di Desa Banyubiru meletakan tradisi ini menjadi sesuatu yang sangat penting, ada berbagai ritual untuk mendoakan dan menghormati leluhur mereka. Ini sesuai dengan gambaran bahwa orang Jawa menjadikan tradisi ziarah kubur menegaskan bahwa kematian tidak berarti kepunahan melainkan kesuburan. Orang-orang yang menjalankan ziarah kubur menyelipkan harapan bahwa kesulitan hidupnya sehari-hari dapat terbantu oleh rahmat atau berkah pangestu yang memberi kekuatan dan menjanjikan kesejahteraan serta keselamatan dari segalanya. (Subagyo, 2004: 146).

Pengetahuan yang didapat secara turun temurun ini menjadikan pegangan dalam kehidupan sehari-hari. Sehingga ini menjadi sistem panoptik karena masyarakat Jawa merasa terkontrol oleh pengetahuan ini. Menurut Foucault "Panoptik bisa berfungsi sebagai usaha menciptakan penyeragaman dalam hubungan dengan orang di tengah kehidupan sehari-hari” (Foucault, 1995: 205). Pengetahuan di sekitar ziarah kubur mengontrol perilaku masyarakat dalam kesehariannya, mereka memiliki rasa bersalah ketika tidak melakukan ziarah kubur. Rasa bersalah ini muncul karena tidak mengirim doa dan mohon pangestu pada roh leluhur. Tidak terkecuali Jemaat GKJ, sebagai manusia Jawa juga merasa terawasi dengan pemahaman ini. Mereka masih melakukan slametan sesuai dengan hitungan atau petungan Jawa. Seperti apa yang diungkapkan oleh Pdt Setyo Utomo tanggal 9 September 2013,

"Mengapa harus sesuai 3 hari, 7 hari, 40 hari, 100 hari, dan 1000 hari, ya karena manusia Jawa. Menjaga rasa was sumelangnya (kekawatiran) tetap harus kita hargai."

Ungkapan ini memperlihatkan, ternyata jemaatnya (GKJ Banyubiru) masih ada rasa was sumelang (ketakutan) ketika tidak sesuai atau melanggar tradisi Jawa. Secara tidak langsung memperlihatkan bahwa pemahaman akan tradisi Jawa berkaitan dengan tradisi ziarah kubur atau penghormatan leluhur sudah tertanam dalam diri jemaat GKJ.

Slametan kematian ataupun ziarah kubur dalam tradisi Jawa, selain petungan 
hari, juga harus ada uburampe. Hal ini berkaitan dengan pralambang atau simbol yang digunakan oleh masyarakat Jawa. Misalnya uburampe yang harus ada saat genduren memperingati arwah adalah pisang dan juga kue apem. Orang Jawa meyakini pisang menjadi pralambang tongkat, sedangkan apem adalah payung. Tongkat payung ini akan digunakan leluhur yang telah meninggal sebagai sarana perjalanan mereka setelah kematian.

Jemaat GKJ dalam ritual genduren ternyata juga menggunakan sarana tersebut, namun dengan pemaknaan yang berbeda. Seperti apa yang diungkapkan Bapak Siswantoro tanggal 12 September 2013, salah satu jemaat GKJ berikut:

"Uburampe dalam slametan saya maknai hanya sebagai simbol saja, dengan simbol orang bisa lebih mendekat. Kita sebagai orang Kristen bisa juga menerima budaya atau tradisi di daerah itu. Hanya menerima dengan makna yang berbeda karena bagaimanapun orang Kristen hidup di tengah masyarakat. Dengan kata lain jaga rasa dengan warga lain."

\section{Jemaat GKJ menggunakan} uburampe dalam tradisi jawa karena ingin menjaga perasaan dengan warga lain. Mereka masih memiliki ketakutan untuk begitu saja meninggalkan tradisi Jawa. Ada ketakutan yang muncul di tengah masyarakat, sehingga ada usaha untuk tetap menjalankan tradisi Jawa sebagai usaha jaga rasa, namun dilakukan dengan pemaknaan yang berbeda dari keyakinan dalam tradisi Jawa.

Dua kekuatan pengetahuan antara "kebenaran" akan Alkitab dan juga aturan komunal masyarakat Jawa ini menjadi pertarungan untuk menegosiasikan identitas Jemaat GKJ. Pada akhirnya Jemaat GKJ harus mengambil sikap tetap menjadi orang Jawa namun tetap meyakini ajaran Kristen. Tetap menjadi orang Jawa, meskipun tidak semua pemahaman dan keyakinan Jawa tradisional menjadi cara pandang mereka. Dalam persoalan ziarah kubur dan juga slametan tetap dilakukan dengan esensi dan pemaknaan yang berbeda.

\section{Penutup}

Berdasarkan penelitian ini terlihat jemaat GKJ memiliki keraguan untuk begitu saja meninggalkan tradisi Jawa, sehingga ada usaha untuk tetap menjalankan ziarah kubur, di sini terlihat adanya bentuk perlawanan terhadap wacana purifikasi. Pada kenyataannya Purifikasi agama tidak berhasil secara total. Jemaat GKJ dalam menegosiasikan identitasnya, tetap menjalankan tradisi Jawa dengan 
pemaknaan yang berbeda. Negosiasi identitas jemaat GKJ bersifat kreatif. Secara personal mereka menggunakan bentuk tradisi ziarah kubur sebagai wujud hormat bakti pada leluhurnya, sedangkan secara komunal ziarah kubur tetap dilakukan sebagai usaha penerimaan identitasnya sebagai manusia Jawa.

\section{DAFTAR PUSTAKA}

Beatty, Andrew. 2001. Variasi Agama di Jawa: Suatu Pendekatan Antropologi, (terj). Achmad Fedyani Saefuddin, dari judul Asli, Varieties of Javanese Religion, Jakarta: PT. RadjaGrafindo Persada.

Darusuprapta. 1988. Sarasehan Kebudayaan Jawi dalam Yatmana, Tuntutan Kagem Pranatacara Tuwin Pamedhar Sabda. Semarang: Aneka Ilmu.

Endraswara, Suwardi. Mistisme dalam Seni Spiritual Bersih Desa di Kalangan Penghayat Kepercayaan. Yogyakarta: Jurnal Kebudayaan Jawa Kejawen, Vol. 1, No. 2., Agustus 2006. Jurusan Pendidikan Bahasa Daerah Fak. Bahasa Seni UNY \& Narasi Yogyakarta.

Foucault, Michel. 1978. The history of Sexulity: Volume I An Introduction, New York: Pantheon Books.

Foucault, Michel . 1995. Discipline \& Punish: The Birth of the Prison (New York: Vintage Books) translated from the French by Alan Sheridan.

Geertz, Clifford. 1981. Abangan, Santri, Priyayi, dalam Masyarakat Jawa (terj),
Aswab Mahasin, dari judul asli, The Religion of Java. Jakarta: Dunia Pustaka Jaya.

Guillot, C. 1985. Kiai Sadrach; Riwayat Kristenisasi di Jawa. Jakarta: Temprint.

Hardjana, Agus M. 2005. Religiositas, Agama, dan Spiritualitas. Yogyakarta: Kanisius.

Harsapandi. 2005 Suran: Antara Kuasa Tradisi dan Ekspresi Seni. Yogyakarta: Pustaka Marwa.

Haryatmoko. 2010. Dominasi Penuh Muslihat akar kekerasan dan Diskriminasi. Jakarta: Gramedia.

James, William. 2003. The Verieties of Religious Experience. Alih bahasa Luthfi Anshari. Yogyakarta: Jendela.

Keane, Webb. 2007. Christian Moderns: Freedom and Fetish in the mission encounter. Los Angels: University of California Press.

Lukito, Lucas. 2009. 500 Tahun Yohanes Calvin: Pengetahuan Tentang Allah adalah Testing Ground untuk Mengenal Manusia. Veritas-Jurnal Teologi dan Pelayanan, SAAT Malang

Prasetya, F. Mardi. 1993. Psikologi Hidup Rohani 1. Yogyakarta: Kanisius.

Saukko, Paula. 2003. Doing Research in Cultural Studies: An Introduction to Classical and New Methodological Approach, London: Sage.

Subagya, T.L. 2004. Menemui Ajal; Etnografi Jawa tentang Kematian. Yogyakarta: KEPEL Press.

Suseno, Franz Magnis.1988. Etika Jawa: Sebuah analisa falsafi tentang kebijaksanaan hidup Jawa. Jakarta: Gramedia. 
Soekotjo, S.H. 2009. Sejarah Gereja-Gereja Kristen Jawa (GKJ) Jilid 1: Di Bawah Bayang-Bayang Zending (1868-1948). Yogyakarta: Taman Pustaka Kristen.
Wisnumurti, Rangkai. 2012. Sangkan Paraning Dumadi: Konsep Kelahiran dan Kematian Orang Jawa. Yogyakarta: Diva Press. 